(c) Copyright, Princeton University Press. No part of this book may be

distributed, posted, or reproduced in any form by digital or mechanical means without prior written permission of the publisher.

\title{
Introduction: \\ Finance, Stewardship, and Our Goals
}

W $\begin{aligned} & \text { hat are we to make of a book called } \\ & \text { Finance and the Good Society? To some }\end{aligned}$ readers, this may seem an incongruous coupling of concepts. The word finance is commonly thought of as the science and practice of wealth management-of enlarging portfolios, managing their risks and tax liabilities, ensuring that the rich grow richer. We will revisit-and challenge-this definition of finance later in this chapter. The phrase good society is a term used by generations of philosophers, historians, and economists to describe the kind of society in which we should aspire to live; it is usually understood as an egalitarian society, one in which all people respect and appreciate each other. So at first glance finance, at least as commonly understood, seems to be working against the achievement of the good society.

But it is not so simple. Finance has become ever more associated with capitalism. Since the Industrial Revolution, intellectuals have focused their often heated debates about the good society on issues related to capitalism, including the system of markets, private property, legal rules, and class relations. These institutions and issues have increasingly come to define modern society throughout the world. Along with democracy, few ideas have been as pervasive and contentious in defining the good society as capitalism.

Debates about capitalism and the good society, from Karl Marx's incendiary criticisms in the nineteenth century through Milton Friedman's spirited defenses of free markets in the twentieth, have tended to center on industrial capitalism: the system of production, banking, and trade that shaped modern society up through the end of World War II. But the past several decades have 
(c) Copyright, Princeton University Press. No part of this book may be

distributed, posted, or reproduced in any form by digital or mechanical means without prior written permission of the publisher.

witnessed the rise of financial capitalism: a system in which finance, once the handmaiden of industry, has taken the lead as the engine driving capitalism. Much ink has been spilled over the purely economic aspects of financial capitalism. I too have contributed to this discussion, in my scholarly writings on market volatility and in books such as Irrational Exuberance. The current severe financial crisis has called forth questions not only about the system's parts but also about financial capitalism as a whole. This crisis-dubbed by Carmen Reinhart and Kenneth Rogoff as the "Second Great Contraction," a period of weakened economies around the world starting in 2007 but continuing for years after, mirroring the Great Contraction that followed the financial crisis of 1929- has led to angry rejections of the value of financial capitalism.

Given this experience, many wonder, what is the role of finance in the good society? How can finance, as a science, a practice, and a source of economic innovation, be used to advance the goals of the good society? How can finance promote freedom, prosperity, equality, and economic security? How can we democratize finance, so as to make it work better for all of us?

\section{What's in a Phrase? Financial Capitalism Evolving}

The term financial capitalism developed negative connotations as soon as it first became popular in the 1930s with the publication of George W. Edwards's The Evolution of Finance Capitalism. ${ }^{1}$ Edwards saw a conspiracy of large financial institutions, with J. P. Morgan at the lead. He called it the Pax Morgana. During the Great Depression critics and much of the public at large blamed the financial system for their plight; they viewed the system as almost feudal, with financiers replacing the lords.

The term has recently been revived, and again it is used with hostility. President Nicolas Sarkozy of France has said,

Purely financial capitalism has perverted the logic of capitalism. Financial capitalism is a system of irresponsibility and is ... amoral. It is a system where the logic of the market excuses everything. ${ }^{2}$

Tony Blair, former British prime minister, speaking of the severe financial crisis that began in 2007, remarked,

What is plain is that the financial system has altered its fundamentals, and can never be the same again. What is needed is radical action to deal with the fallout of the crisis. ${ }^{3}$

Grigory Yavlinsky wrote the 500 Days Program of 1990, which outlined the Russian transition to a free-market economy, and was promoted to deputy prime minister to implement it. He began to express similar doubts after the crisis. In his 2011 book Realpolitik, in a section entitled "Structural Shift: From Industrial Capitalism to Financial Capitalism," he noted that 
(c) Copyright, Princeton University Press. No part of this book may be

distributed, posted, or reproduced in any form by digital or mechanical means without prior written permission of the publisher.

the fundamental structural shifts [are] directly related to a gradual slackening of moral constraints in developed countries. Structural shifts like these follow very fast growth of the financial sector and services directly related to it. ${ }^{4}$

I argue in this book that while critics are correct in some of their indictments, the changes that must be made, rather than having the effect of constraining the innovative power of financial capitalism, should instead broaden its scope. We will make little progress if we simply condemn financial capitalism as a "system of irresponsibility." But we have the potential to support the greater goals of good societies-prosperous and free societies in the industrialized as well as the developing world-if we expand, correct, and realign finance.

\section{The Inexorable Spread of Financial Capitalism}

At the time of this writing we are still stuck in the severe financial crisis that began in 2007. As such we tend to associate finance with recent problems, such as the mortgage and debt hangovers in the United States and Europe, and with the legal and regulatory errors that preceded these events. But we should not lose sight of the bigger picture. The more important story is the proliferation and transformation of successful financial ideas. Financial innovations emanating from Amsterdam, London, and New York are developing further in Buenos Aires, Dubai, and Tokyo.

The socialist market economy, with its increasingly advanced financial structures, was introduced to China by Deng Xiaoping starting in 1978, adapting to the Chinese environment the examples of other highly successful Chinese-speaking cities: Hong Kong, Singapore, and Taipei. The economic liberalization of India, which allowed freer application of modern finance, was inaugurated in 1991 under Prime Minister P. V. Narasimha Rao by his finance minister (later prime minister) Manmohan Singh, who was educated in economics at Nuffield College, Oxford University. The voucher privatization system introduced to Russia in 1992-94 under Prime Minister Boris Yeltsin by his minister Anatoly Chubais, following a modification of the Yavlinsky plan, was a deliberate and aggressive strategy to transform Russia's economy. The intent was not simply to match the rest of the world in the degree to which finance permeated the daily lives of the Russian people, but to have Russia rank first in the world in public ownership of capital.

Such sudden integrations of sophisticated financial structures, originally designed in more financially advanced countries, were not achieved entirely smoothly in these countries, and there was a degree of anger about the inequality of benefits that accrued to some, as opportunists amassed great wealth quickly during the transitions. But China, India, and Russia have seen a flourishing of financial sophistication and amazingly high economic growth rates. And it is not just these countries. According to International Monetary Fund 
(c) Copyright, Princeton University Press. No part of this book may be distributed, posted, or reproduced in any form by digital or mechanical means without prior written permission of the publisher.

data, the entire emerging world-including the Commonwealth of Independent States, the entire Middle East, Sub-Saharan Africa, and Latin Americahas proved able to generate annual gross domestic product (GDP) growth of over $6 \%$ during the past decade, when not compromised by world financial crises. $^{5}$

In addition, a host of international agreements have created institutions that work for the betterment of humankind using sophisticated financial tools. The World Bank, founded in 1944 and today expanded into the massive World Bank Group, has engraved on its headquarters in Washington, D.C., the motto "Working for a World Free of Poverty." The World Bank was only the first of the multilateral development banks: the African Development Bank, the Asian Development Bank, the European Bank for Reconstruction and Development, the Inter-American Development Bank Group, and many others.

Modern financial institutions are pervasive throughout the world today. Moreover, it is not just stocks or bonds that represent financial markets. One might not at first consider the price of agricultural commodities as relevant to a discussion of financial instruments, but the prices that they fetch on futures exchanges are entirely analogous to prices in the stock and bond markets. Wheat and rice markets are financial markets too, in the sense that they engage in similar activities and rely on comparable technical apparatus, and they are similar in their fluctuations and their impact on the economy. The fact that the very lives of low-income people around the world depend on food prices in some of these markets only underscores the significance of our financial institutions - and the importance of getting these institutions right.

\section{Financial Capitalism and Marxian Communism}

The triumph of financial capitalism or its analogues since the 1970s, even in formerly Marxian communist countries, is one of the most significant revolutions in history, and a radical departure from the past.

Communism, in its modern form, had its defining moment in 1848, the year that saw a number of popular uprisings in cities around Europe. Those revolts of the working class did not have an effective leader and were not by themselves communist in nature. They sprang forth from general dissatisfaction at the roots of society. But they created an opportunity for the communist movement to take hold.

Karl Marx and Friedrich Engels recognized the significance of these events and in the same year, with the support of the Communist League (originally a Christian organization), published their brief Communist Manifesto-which came across as quite radical and un-Christian. It advocated violent revolution, and Marx and Engels were eventually perceived by many as filling the leadership void in the revolutions of 1848 . Even though those revolutions were short 
(c) Copyright, Princeton University Press. No part of this book may be

distributed, posted, or reproduced in any form by digital or mechanical means without prior written permission of the publisher.

lived, their manifesto came to be seen as speaking for the many who had previously remained silent.

The word communism comes from the old French commun, meaning common, and refers to the original central tenet of this belief system: the common ownership of capital, the means of production. In this book I refer to the traditional form of communism, not the socialist market economy promoted by the Communist Party in China today, which allows-and even actively encourages-private ownership among members of the public.

The central argument for public ownership of capital was, according to Marx in his Capital, to break a vicious cycle of poverty:

It is not because he is a leader of industry that a man is a capitalist; on the contrary, he is a leader of industry because he is a capitalist. The leadership of industry is an attribute of capital, just as in feudal times the functions of general and judge were attributes of landed property. . . . The capitalist system presupposes the complete separation of the laborers from all property in the means by which they can realize their labor. . . . The process, therefore, that clears the way for the capitalist system, can be none other than the process which takes away from the laborer the means of his production; a process that transforms on one hand, the social means of subsistence and of production into capital, on the other, the immediate producers into wage laborers. ${ }^{6}$

Marx never explains clearly why it is that laborers do not have access to capital. He implies that under capitalism the goals of society are set by those at the top—-those with access to capital—and not by all the people. It remains an unstated assumption that a poor laborer could never start a business by getting credit from a bank or capital from wealthy investors.

But in an ideal capitalist system, people with good business ideas can, in principle at least, do just that. Our capitalist institutions do not yet fully live up to this ideal, but throughout history there has been a long trend toward the democratization of finance, the opening of financial opportunities to everyone. It is a trend we must hope will continue into the future.

It is true that social barriers prevent some from realizing, and profiting from, their talents. An illiterate farm boy from a remote area finds it difficult to walk into the offices of a bank in a big city to ask for capital to start a business. There is a very real barrier to such people's accessing capital, and there is substantial evidence of such a barrier in the extreme variation in interest rates paid by borrowers in different regions and different categories. Development economist Esther Duflo summarizes: "This body of evidence makes it very hard to believe that credit markets, at least in the developing world, are anywhere near the ideal market that would make the distribution of wealth irrelevant for investment." 7

But this is not a fundamental problem of financial capitalism. It is rather a problem of democratizing and humanizing and expanding the scope of financial 
(c) Copyright, Princeton University Press. No part of this book may be

distributed, posted, or reproduced in any form by digital or mechanical

means without prior written permission of the publisher.

capitalism. The same basic issue would remain in Marx's new society. It is a social dilemma that can be addressed by changes in our educational system. Indeed we have already started to change the system around the world with improved public education and communications. ${ }^{8}$

\section{Financial Capitalism Comes of Age}

We do indeed live in the age of financial capitalism. We should not regret that. Regulations and restrictions can and should be placed on financial institutions to help them function in the best interests of society, but the underlying logic and power of these institutions remains central to their role. Financial institutions and financial variables are as much a source of direction and an ordering principle in our lives as the rising and setting sun, the seasons, and the tides.

Indeed there appears to be no viable alternative. We never hear talk of nonfinancial capitalism as a model-although one could use such a term to refer to a market economy with poorly developed financial institutions, as we still see today in some poorer regions of the world. As much as we might like to criticize finance, no one seems to view these alternatives as suitable models for anyone's future.

Our task, both in the financial sector and in civil society, is to help people find meaning and a larger social purpose in the economic system. This is no small feat, with all the seemingly absurd concentrations of wealth the system brings about, the often bewildering complexity of its structures, and the games-often unsatisfying and unpleasant-it forces people to play.

Definitions matter, and so how we define financial capitalism - getting that definition right-will help us develop a working theory of this most important force. It should set a norm for how finance works and what leaders within business, the public sector, and civil society must do to harness emerging developments within the field of finance to support the goals of a robust and prosperous economy, to curb its excesses, to smooth its volatility, and to consider how finance can be brought to bear to address the needs of advanced and developing economies alike.

\section{Toward a Working Theory of Financial Capitalism}

At its broadest level, finance is the science of goal architecture-of the structuring of the economic arrangements necessary to achieve a set of goals and of the stewardship of the assets needed for that achievement. The goals may be those of households, small businesses, corporations, civic institutions, governments, and of society itself. Once an objective has been specified-such as payment for a college education, a couple's comfortable retirement, the opening of a restaurant, the addition of a new wing on a hospital, the creation of a social security system, or a trip to the moon-the parties involved need 
(c) Copyright, Princeton University Press. No part of this book may be

distributed, posted, or reproduced in any form by digital or mechanical means without prior written permission of the publisher.

the right financial tools, and often expert guidance, to help achieve the goal. In this sense, finance is analogous to engineering.

It is a curious and generally overlooked fact that the very word finance actually derives from a classical Latin term for "goal." The dictionary tells us that the word derives from the classical Latin word finis, which is usually translated as end or completion. One dictionary notes that finis developed into the word finance since one aspect of finance is the completion, or repayment, of debts. But it is convenient for our purposes to recall that finis, even in ancient times, was also used to mean "goal," as with the modern English word end.

Most people define finance more narrowly. Yet financing an activity really is creating the architecture for reaching a goal—and providing stewardship to protect and preserve the assets needed for the achievement and maintenance of that goal.

The goals served by finance originate within us. They reflect our interests in careers, hopes for our families, ambitions for our businesses, aspirations for our culture, and ideals for our society; finance in and of itself does not tell us what the goals should be. Finance does not embody a goal. Finance is not about "making money" per se. It is a "functional" science in that it exists to support other goals-those of the society. The better aligned a society's financial institutions are with its goals and ideals, the stronger and more successful the society will be. If its mechanisms fail, finance has the power to subvert such goals, as it did in the subprime mortgage market of the past decade. But if it is functioning properly it has a unique potential to promote great levels of prosperity.

The attainment of significant goals and the stewardship of the assets needed for their achievement almost always require the cooperation of many people. Those people have to pool their information appropriately. They must ensure that everyone's incentives are aligned. Imagine the development of a new laboratory, the funding of a medical research project, the building of a new university, or the construction of a new city subway system. Finance provides structure to these and other enterprises and institutions throughout society. If finance succeeds for all of us, it helps to build a good society. The better we understand this point, the better we will grasp the need for ongoing financial innovation.

\section{What Finance Does}

Economists and finance professionals tend to define and discuss finance in narrower terms than those we've been employing here. Much research in academic finance is focused on short-term trading strategies and results, and on the related topic of risk management. In its canonical form, academic finance is the science of designing optimal portfolios of investments. Day-to-day 
(c) Copyright, Princeton University Press. No part of this book may be

distributed, posted, or reproduced in any form by digital or mechanical means without prior written permission of the publisher.

activities on Wall Street likewise tend to be concentrated on highly specified activities. But this is only part of what finance really involves.

An essential part of what finance professionals actually do is dealmakingthe structuring of projects, enterprises, and systems, large and small-an activity that brings convergence to individuals' often divergent goals. Financial arrangements-including the structuring of payments, loans, collateral, shares, incentive options, and exit strategies-are just the surface elements of these deals. Dealmaking means facilitating arrangements that will motivate real actions by real people - and often by very large groups of people. Most of us can achieve little of lasting value without the cooperation of others. Even the archetypal solitary poet requires financing to practice her or his art. An income to live on, publishers, printers, arrangers of public readings, the construction of suitable halls for public readings-there is a hidden financial architecture behind all of this.

All parties to an agreement have to want to embrace the goal, do the work, and accept the risks; they also have to believe that others involved in the deal will actually work productively toward the common goal and do all the things that the best information suggests should be done. Finance provides the incentive structure necessary to tailor these activities and secure these goals.

In addition, finance involves discovery of the world and its opportunities, which ties it in to information technology. Whenever there is trading, there is price discovery - that is, the opportunity to learn the market value of whatever is being traded. This in turn involves the revelation of people's feelings and motivations, and of the opportunities that exist among groups of people, which may in turn make even more ambitious goals possible.

Along with being the science that structures the achievement of goals, finance embodies a vital technology. As such, it has demonstrated continuous progress over the centuries, from the beginnings of money lending in the ancient world through the development of modern mortgage markets as well as the legal and regulatory structures necessary to sustain these innovations. And it will continue to progress. Finance, suitably configured for the future, can be the strongest force for promoting the well-being and fulfillment of an expanding global population-for achieving the greater goals of the good society.

\section{Finance Meets the Good Society}

The real cure for the problem that Marx addressed lies not in destroying the capitalist system but in improving and democratizing it—and improving it means serving the greater goals of the good society. That has always been the best response, to the dismay of radicals.

The essential challenge for leaders to contemplate in coming to terms with the future of finance is to understand that it can be used to help broaden 
(c) Copyright, Princeton University Press. No part of this book may be

distributed, posted, or reproduced in any form by digital or mechanical means without prior written permission of the publisher.

prosperity across an increasingly wide range of social classes, and that its products can be made easier for people to use and can be better integrated into the economy as a whole.

On the first point, there is nothing in financial theory that specifies that control of capital should be confined to a few "fat cats." Think of the broadly democratic proliferation of insurance, mortgages, and pensions-all basic financial innovations-in underwriting the prosperity of millions of people in the past century. Further perfecting financial institutions and instruments through innovations large and small will enable society to enlarge the scope of this prosperity and reverse the growing trend toward social inequality.

Regarding the second point, designing financial institutions around real human quirks will make it easier for people to adapt financial innovations to their lives and for the financial system as a whole to function more smoothly. This means that psychologists have to be on the financial team, and we must also take account of the revolution in behavioral economics and behavioral finance that has occurred in the past few decades. ${ }^{9}$ It means that we must smooth the rough edges off our financial system-those aspects that can cause trouble when people make mistakes. It means that people have to be told the truth about the financial contracts into which they enter, and about the ways in which those contracts could be hurtful in the future, so that they can take full account of their emotions and wants before they sign a contract.

If we extrapolate historical trends, it will be possible to further extend the scope and range of financial capitalism and render Marx's criticism-the fundamental basis for his vision of the communist extreme-forever obsolete. Accomplishing this goal will require a degree of government intervention, but not intervention that would frustrate market solutions. Government's task in this endeavor is to provide a clear set of rules for the game, one that protects consumers and promotes the public interest while enabling the players to compete in doing what they do best: delivering better products and services. A real challenge in this regard is that these rules must have an international dimension, as today's financial markets are both global in reach and instantaneous in effect.

\section{Tomorrow's Opportunity: Financial Capitalism in the Information Age}

In his 1995 book The Road Ahead, Bill Gates made a number of predictions about our future in the information age, most of them fanciful. The majority of the more amusing predictions have not yet come to pass. For example, he predicted that some of us will record our entire lives, running video recorders all the time and storing our entire video biographies for future viewing. That idea made for thought-provoking reading, but it hasn't yet become a reality. What Gates did not predict were numerous other fundamental developments, 
(c) Copyright, Princeton University Press. No part of this book may be distributed, posted, or reproduced in any form by digital or mechanical means without prior written permission of the publisher.

including the web sites eBay (founded in 1995, the very year his book appeared), Wikipedia, Facebook.com, LinkedIn.com, Zipcar.com, CouchSurfing .org, and a million others that have changed the way we live our lives. He shouldn't be faulted for failing to predict these-no one could have. Instead we should consider the process through which such innovations happen, and why they happen more in certain environments than in others. That is the real subject of finance.

Bill Gates was not presenting a vision of the future of capitalism or of the good society; he was captivated by the engineering details. His predictions seemed to center on little things, on gimmicks. He also did not choose to look very far ahead. The real issue is: What can capitalism do for the good society, with all of the complexity and information linkages a society involves? What little things, in concert with other little things, have the potential to strengthen our sense of fulfillment in our lives? Consider a "little" thing like Facebook, not predicted by Bill Gates in 1995, which can reunite old friends across the years. Is this an important innovation for achieving the good society? It could be, in the sense that it gives people a sense of completion in their lives.

The rapid advance of information technology in this century portends numerous-and often frightening - changes, for machines are rapidly replacing human intelligence. A computer program named Soar has the ability not only to play games against humans but also to learn how to play new kinds of games as well. ${ }^{10}$ The DeepQA program invented at IBM by a group led by David Ferruci can recognize speech and answer general-knowledge questions. The program has been tested in simulated appearances on the television quiz show Jeopardy, and it appears to be able to beat human contestants. ${ }^{11}$

Hearing about such innovations can be demoralizing. We all want to develop our skills to compete as effectively as possible and be successful in the working world. There is no sense in acquiring talents that will be replaced by machines. Unfortunately, it is hard to predict which talents will ultimately matter.

In their 2005 book The New Division of Labor: How Computers Are Creating the Next Job Market, labor economists Frank Levy and Richard J. Murnane argue that computers are replacing routine tasks yet cannot perform what they call "expert thinking" or "complex communication." In fact, computers are more likely to create jobs requiring these human talents than displace humans from them. ${ }^{12}$

Expert thinking means thinking broadly, interpolating different sources of information and information from different perspectives-information about what is new and current as well as what is perennial and has been forgotten. An example of an expert thinker given by Levy and Murnane is the auto mechanic who is familiar with the computerized diagnostic routines required by modern automobile makers, knows where parts can be found cheaply, is 
(c) Copyright, Princeton University Press. No part of this book may be

distributed, posted, or reproduced in any form by digital or mechanical means without prior written permission of the publisher.

aware of the needs of a variety of customers, and can sense by test driving a car what really should be done.

Complex communication refers to the combination of interpersonal skills and understanding complex situations. An example offered by the authors is that of a lawyer, who not only knows the intricacies of the law but also understands what is really in the best interest of the client, given the client's situation, and can communicate this knowledge to the client persuasively.

It is not possible to predict which broad job categories will survive in the face of increasingly sophisticated information technology, for every major occupational group will continue to include some jobs that provide opportunities for both expert thinking and complex communication. But finance, broadly construed, is a field in which such jobs may be especially likely to survive and perhaps even proliferate. Jobs that involve finance are a little like those of the auto mechanic and the lawyer. One must understand the technicalities of financial engineering just as the auto mechanic understands mechanical engineering, and be able to apply that knowledge and sensibility to human problems. One must understand the intricacies of financial institutions (and the legal framework that defines them) and be able to communicate that knowledge to a client.

This process has been defining the history of financial innovation for generations. On the streets of New York in the 1840s one would see boys running back and forth, delivering checks, drafts, and other negotiable instruments to the various windows inside banks, and receiving gold and banknotes in exchange. All that disappeared after 1853, with the founding of the New York Clearing House, which soon had fifty-four bank members. This was an important innovation in information technology, even though it might not meet our current idea of such technology since it did not involve any electronics. At ten o'clock every morning representatives of all the major banks would sit down in a large room, each at a designated desk, with all the desks arranged in a circle. A clerk for each of the representatives would then get up from his desk and, simultaneously with all the other clerks, make a round of all the other fifty-three desks, dropping off fifty-three bundles of documents, one for each of the other banks. The whole process took no more than six minutes. Any imbalances would then be summed and paid in gold or banknotes, not by the banks to one another, but to the Clearing House. The jobs of delivering documents and cash on the street faded. But finance itself had not faded. ${ }^{13}$

The technology of clearing improved even more markedly with the advent of the computer. Indeed artificial intelligence systems like DeepQA will soon be available that will be able to answer Jeopardy-like questions about finance. With all these continuing advances in technology, one may wonder what will be left of many jobs in the future. But, for the foreseeable future, computers will not be able to counsel people effectively on what they really need to do with their portfolios, nor to make deals among companies, nor to advise a 
(c) Copyright, Princeton University Press. No part of this book may be distributed, posted, or reproduced in any form by digital or mechanical means without prior written permission of the publisher.

university department about a new research project, nor to do any of a large number of other jobs. For finance is still about achieving human goals-a task that machines cannot handle in any but the most basic of ways.

We shall see in this book that democratizing finance entails the development of both human arrangements-such as those for financial advice, legal advice, and financial education-and technology that works together with these human arrangements to make it possible for everyone to participate intelligently in the financial system.

\section{Financial Activities in the Economy}

Financial activities consume an enormous amount of time and resources, increasingly so over the years. The gross value added by financial corporate business was $9.1 \%$ of U.S. GDP in 2010, continuing a long upward trend. By comparison it was only $2.3 \%$ of GDP in $1948 .{ }^{14}$ These figures exclude many more finance-related jobs, such as insurance. ${ }^{15}$ Information technology certainly hasn't diminished the number or scope of jobs in finance.

To some critics, the current percentage of financial activity in the economy as a whole seems too high, and the upward trend is cause for concern. But how are we to know whether it really is too high or whether the trend is in fact warranted by our advancing economy? What standard do we have? People in the United States spend $40 \%$ as much (3.7\% of GDP) eating out at restaurants as the corporate financial sector consumes. ${ }^{16}$ Is eating out a wasteful activity when people could just as well stay home and eat?

Surely at least a part of what all these finance professionals are doing is productive: a good number of them are evaluating businesses and directing resources to the more promising of these. But other types of financial activitytrying to outguess the psychology of the market, carrying out high-frequency trading, or advertising dubious financial products-seem not to be very productive.

Arjun Jayadev and Samuel Bowles have estimated that 19.7\% of the U.S. labor force in 2002-supervisors, security personnel, members of the military-was involved in guarding in some form. ${ }^{17}$ The high percentage of our citizens paid to guard us and our installations and possessions is at its essence surely more troubling than the percentage engaged in the substantially productive activities of finance. Yet relatively few of us seem bothered by this statistic.

\section{Financial Capitalism and the Challenge of Financial Innovation}

While financial capitalism inevitably must be made to serve the good society, it cannot be summarized in simple terms. This is so because it represents a 
(c) Copyright, Princeton University Press. No part of this book may be

distributed, posted, or reproduced in any form by digital or mechanical means without prior written permission of the publisher.

bewilderingly broad and cross-cutting array of institutions, instruments, and markets, each element of which evolved through a process of invention not unlike the processes that produced our automobiles and airplanes, and through which they continue to evolve.

Financial innovation is an underappreciated phenomenon. According to Google Ngrams, the term financial innovation was hardly ever used until the late 1970s and 1980s. The term seems to have been applied first to the controversial financial futures markets that developed around that time. It was shortly thereafter that patent offices began to accept claims for financial innovations. For example, the U.S. Patent and Trademark Office granted patent number 4,346,442 to what is now Merrill Lynch in 1982 for its Cash Management Account (CMA).

That was a landmark change. Why had the patent authorities not previously thought of financial methods as patentable? A clue can be found in a 1908 U.S. Second Circuit Court decision in the case of Hotel Security Checking Co. v. Lorraine, which set a "business method exemption doctrine" that held sway until around the time of the Merrill CMA decision. The 1908 court held that business methods, whether original or not, are uniformly unpatentable. ${ }^{18}$ In its decision, the court emphasized that the patent granted, a method for detecting fraud in accounting, used only paper and ink and business common sense. The wording suggested that the court was looking for some proof of concrete innovation as manifested in the "physical means employed."19 Financial patents thus awaited the application of computers to financial innovation, as in Merrill Lynch's 1982 patent; a computer programmed to perform a financial service could, at least by the 1908 standard, be considered a physical means.

A problem with patenting financial innovations is that they interact with the whole economy; they may produce consequences-including winners and losers-that are evident only years later. The applicant for a financial patent cannot prove the efficacy of the invention as can the inventor of a device submitted for an engineering patent. Since financial innovations interact with people's foibles-their hopes, their promises, their life savings-patents on them seem to be inherently more controversial than engineering patents. Most financial patents that do not require complex computerized implementation would seem likely to have a long history of prior art that was implemented in some rudimentary form, if never well documented. Indeed a common reaction to many financial patents (including the original 1982 Merrill Lynch CMA patent) has been that they lack the kind of originality underlying inventions of physical devices.

But the process of financial innovation is still important, even if it is more at the level of corporate and societal innovation than lone-inventor-in-the-lab creativity. When we describe finance, and how it succeeds, we are aiming at a moving target. Leaders must understand that financial innovation is a messy and sometimes disruptive process. In this book, descriptions of financial 
(c) Copyright, Princeton University Press. No part of this book may be

distributed, posted, or reproduced in any form by digital or mechanical means without prior written permission of the publisher.

products and institutions will have interspersed among them possible directions for future innovation and change.

\section{What Follows in This Book}

This book develops a working theory of financial capitalism to help guide the greater discussion of finance and the good society. It begins, in Part One, with the realities of financial capitalism, as it is constituted today and will be constituted in the future. This part looks at the roles and responsibilities that people take on in the field of finance, from investment bankers through lawyers through regulators and educators. It examines the various organs of the body of financial capitalism - organs that function together to produce a living economic entity, organs that take the form of groups of people bound together in organizations and with particular traditions and ways of operating.

There is an unfortunate tendency to talk about the financial system in the abstract, as if it is all about stocks and bonds, or about mathematical equations. But the drivers of financial capitalism are real men and women, who adopt certain personae in our society and make the goals inherent in these roles their own personal goals and the responsibilities associated with these roles their own personal responsibilities. Each such role has its own code of ethics and professional conduct, and it depends on the people filling that role to uphold that code. Here we consider a wide array of such roles, to give a broad picture of the real workings of financial capitalism. As these various roles are discussed, we will consider how they might be improved, and how financial innovation will alter these roles and make the people who assume them more effective.

The public hostility that we see today toward financial capitalism often takes the form of anger directed toward the people who fill certain of these roles. An important mission of Part One is to take account of this public hostility, to try to understand, on a role-by-role basis, why particular roles in the financial system are so controversial.

Part Two of the book takes a more critical look at the financial system that all the people described in the first part have created, and it offers some ideas about how it can and will be improved in the future. It looks at some of the system's strengths and inspirations, but also at its anxieties and breakdownsall of which are relevant to any discussion of the role of finance in the good society. The financial system conforms to a large degree to financial theory, which has a sort of beauty that can inspire minds, but also a sort of ugliness, at least in its present form. The financial crises that we experience from time to time are only part of the story. That ugliness can provoke some to dismiss the whole concept of financial capitalism. But it would be foolish to do so, for that would cost us the ability to accomplish some of our most cherished goals. 
(c) Copyright, Princeton University Press. No part of this book may be distributed, posted, or reproduced in any form by digital or mechanical means without prior written permission of the publisher.

The history of the economic development that has brought the world to its current state of prosperity and enlightenment is a history of many technical adjustments to our financial system, of innovations inspired by financial theory but also based on realistic assessments of human nature. This part of the book indulges in extrapolations of past trends that have resulted in better and better financial systems; it also puts forth a number of concrete ideas for how the system can be improved in coming decades.

The epilogue offers some final thoughts on how power is actually wielded in finance, on our negative feelings about the concentration of power we see in the financial world, and on how in a financial democracy such power might be managed and reconciled with basic human values. 